\title{
The scale effect of landscape variables on landscape experiences: A multi-scale spatial analysis of social media data in an urban nature park context
}

Ping Chang ( $\nabla$ chang@hum.ku.dk)

University of Copenhagen: Kobenhavns Universitet

Anton Stahl Olafsson

University of Copenhagen: Kobenhavns Universitet

\section{Research Article}

Keywords: Flickr, cultural ecosystem services, urban nature, multiscale geographically weighted regression, outdoor recreation

Posted Date: March 22nd, 2021

DOI: https://doi.org/10.21203/rs.3.rs-329440/v1

License: (a) (i) This work is licensed under a Creative Commons Attribution 4.0 International License. Read Full License

Version of Record: A version of this preprint was published at Landscape Ecology on January 31st, 2022. See the published version at https://doi.org/10.1007/s10980-022-01402-2. 


\section{Abstract}

Context The roles of landscape variables with regard to the recreational services provided by nature parks have been widely studied. However, the potential scale effects of the relationships of landscape features and attributes to categorized nature experiences have not been adequately studied from an experimental perspective. Objectives This article demonstrates multiscale geographically weighted regression (MGWR) as a new method to quantify the relationship between experiences and landscape variables and aims to answer the following questions: 1) Which dimensions of landscape experiences can be interpreted from geocoded social media data, and what landscape variables are associated with specific dimensions of experience? 2) At what spatial scale and relative magnitude can landscape variables mediate landscape experiences? Methods Social media data (Flickr photos) from Amager Nature Park were categorized into different dimensions of landscape experience. Estimated parameter surfaces resulting from the MGWR were generated to show the patterns of the relationship between the landscape variables and the categorized experiences. Results All considered landscape variables were identified as relating to certain landscape experiences (nature, animals, scenery, engagement, and culture). Scale effects were observed in all relationships. This highlights the realities of context- and place-specific relationships and the limited applicability of simple approaches that assume relationships to be spatially stationary. Conclusions The spatial effect of landscape variables on landscape experiences was clarified and demonstrated to be important for understanding the spatial patterns of landscape experiences. The demonstrated modelling method may be used to further the study of the value of natural landscapes to human wellbeing.

\section{Introduction}

Nature provides numerous ecosystem services (ES) for human and ecological wellbeing (MA 2005; Brown, Montag and Lyon, 2012; de Groot et al. 2010). Four general categories of ecosystem services have been recognized in the ES framework; of these, cultural ecosystem services encapsulate the nonmaterial and intangible values people derive from human-ecosystem relations (Chan et al. 2012), such as "spiritual enrichment, cognitive development, reflection, recreation, and aesthetic experience" (MA 2005, p. 40). People interact with ecosystems in many indirect and direct ways (Russel et al. 2013), but in most cases, the benefits of cultural ecosystem services materialize through actual contact with or being present in ecosystems in the context of recreational activities (Hegetschweiler et al. 2017; O’Brien et al. 2017).

Interactions between humans and the natural environment arise from immersion in the environment that is experienced (Ittelson 1973) and thus are by nature closely associated with landscape features and attributes. The multiscale effects of landscape variables on biological responses have been widely addressed in landscape ecology (Pablo 2018). However, the variability of the scale effects of landscape features and landscape attributes has seldom been studied in social-ecological studies dealing with human responses in terms of recreational landscape experiences. Many different individual, social and physical variables and processes contribute to perceived nature experiences. However, in this rather complicated interaction, in situ experiences are directly linked with landscape settings, where different landscape features and landscape attributes can exert different levels of influence at different spatial scales. For instance, people can relate to a body of water from a long distance away, whereas people tend to experience 
certain landscape features, such as cultural relics, flowers, insects, and man-made features, at a close distance.

There is a rich body of literature exploring interactions between humans and the natural environment and linking these interactions to natural recreational value. The adopted investigation methods include traditional surveys (Sahraoui et al. 2016, Arnberger et al. 2010) and public participation GIS (Heikinheimo et al. 2020; Garcia-Martin, et al. 2016; Brown et al. 2020); recently, analyses of social media data have been used (Johnson et al. 2019; Tenerelli, et al. 2016; Foltête et al. 2020; Pickering et al. 2020; Hamstead et al. 2018; Hausmann et al. 2016; Heikinheimo et al. 2017; Guerrero et al. 2016; Ilieva and McPhearson, 2018). Social media data analyses are based on crowd-sourced big data that are analysed as geocoded points in space expressing landscape experiences or perceived landscape values. In these studies, landscape variables, such as the index of landscape attributes and distance measures to landscape features, are used to identify the associations between the biophysical landscape and landscape experiences. A few recent studies have studied the scale effects of landscape features at the continental level (Gosal et al. 2021) and the national level (Chang Chien, et al. 2020). To our knowledge, no studies have explored such scale effects on in situ landscape experiences on a detailed level based on the types or categories of landscape experiences elicited from social media data. Therefore, little is known about the scale effect of individual landscape features in relation to the on-the-ground experience they stimulate.

In this context, we aim to approach the relationship of landscape experiences to landscape variables with special attention to scale effects and the validation of the results with on-site information. We do so by analysing the spatial relationships of social media data reflecting natural experiences and geospatial data and particularly by linking photos with spatial settings to interpret the revealed patterns based on the following research questions:

1) Which dimensions of landscape experiences can be interpreted from geocoded social media data, and what landscape variables are associated with specific experience dimensions?

2) At what spatial scale and relative magnitude can landscape variables mediate landscape experiences?

\section{Social media data}

Investigating various nature experiences and obtaining comprehensive information about human-nature interactions can be challenging (Heikinheimo et al. 2020). Social media is a new, efficient and simultaneous source for investigating public perceptions and viewpoints (Toivonen et al. 2019), and it has great potential for obtaining knowledge about rather complex nature experiences on an unprecedented scale (Ruths and Pfeffer, 2014). In this context, social media is defined as web-based services where the public can create and share user-generated content (McCay-Peet and Quan-Haase, 2017).

The content of social media data can reveal an individual's in situ experience, reflect how people relate to the surrounding landscape, and enable researchers to tap into the context-dependency and holistic nature of experience (Calcagni et al. 2018). When aggregated, social media data become doubly relational, as what 
people express on social media has inevitably gone through a judgement process by individuals as to what is valued by society, adding a second layer of relationality to social media data (ibid).

Among social media platforms, Flickr has been frequently used in nature-related research because of its orientation towards nature-based activities and nature experiences in content and its relatively minimal access restrictions (Toivonen et al. 2019). Moreover, as photos can be seen as representations of various dimensions of experience (Garrod, 2007), Flickr's image data provide a rich source of information for the identification of natural experiences.

Papers analysing social media data to study the effect of landscape variables have found that different landscape variables may have positive, negative or mixed correlations with data distributions. The findings include that experience location hotspots tend to concentrate around landscape features such as water bodies, tourist attractions and roads as well as areas with high levels of accessibility and openness; a mixed effect was reported from green spaces and areas with high protection status and high land cover diversity (Table 1).

Table 1 Previous findings regarding associations between landscape variables and the concentration of social media data activity

\begin{tabular}{|c|c|c|c|}
\hline Category & $\begin{array}{l}\text { Landscape } \\
\text { variable }\end{array}$ & $\begin{array}{l}\text { Previous publications finding a } \\
\text { positive correlation }\end{array}$ & $\begin{array}{l}\text { Previous publications finding a } \\
\text { negative correlation }\end{array}$ \\
\hline \multirow{4}{*}{$\begin{array}{l}\text { Landscape } \\
\text { features }\end{array}$} & Green space & $\begin{array}{l}\text { Foltête et al. (2020), Wang et al. } \\
\text { (2018), Johnson et al. (2019) }\end{array}$ & $\begin{array}{l}\text { Hamstead et al. (2018), Foltête et } \\
\text { al. (2020), Hausmann et al. (2017) }\end{array}$ \\
\hline & $\begin{array}{l}\text { Water } \\
\text { bodies }\end{array}$ & $\begin{array}{l}\text { Hamstead et al. (2018), Wang et al. } \\
\text { (2018), Tieskens et al (2018) }\end{array}$ & \\
\hline & $\begin{array}{l}\text { Tourist } \\
\text { attractions }\end{array}$ & $\begin{array}{l}\text { Heikinheimo et al. (2020), Wang et } \\
\text { al. (2018) }\end{array}$ & \\
\hline & Roads & $\begin{array}{l}\text { Hamstead et al. (2018), Wang et al. } \\
\text { (2018) }\end{array}$ & \\
\hline \multirow{4}{*}{$\begin{array}{l}\text { Landscape } \\
\text { attributes }\end{array}$} & Accessibility & $\begin{array}{l}\text { Tenerelli et al. (2016), Heikinheimo } \\
\text { et al. (2020), Guerrero et al. (2016) }\end{array}$ & \\
\hline & $\begin{array}{l}\text { Protection } \\
\text { status }\end{array}$ & Tenerelli et al. (2016) & Tenerelli et al. (2016) \\
\hline & $\begin{array}{l}\text { diversity of } \\
\text { land use }\end{array}$ & $\begin{array}{l}\text { Tenerelli et al. (2016), Johnson et } \\
\text { al. (2019) }\end{array}$ & Tenerelli et al. (2016) \\
\hline & Openness & $\begin{array}{l}\text { Foltête et al. (2020), Johnson et al. } \\
\text { (2019), Hausmann et al. (2017) }\end{array}$ & \\
\hline
\end{tabular}

\section{Methods}

\section{Case study area}


Amager Nature Park is a vast green space (3500 ha) situated in the metropolitan area of Copenhagen at the fringe of the city core that provides opportunities for easily accessible natural experiences for citizens of Copenhagen (Fig. 1a). Historically, the majority of this area was underwater except Amager Fælled (the northeastern part), where the land uses (Fig. 1b) historically included military training fields, grazing land and landfill sites, and the southern and southwestern parts, which were dominated by afforestation and a system of old beach meadows (Kaae et al. 2019). During WWII, the rest of the land was reclaimed from the sea, and the construction of the drainage system resulted in more complex and diverse hydrological soil conditions. Military use has been an overarching theme in the area for a long time, leaving much cultural heritage on site. Extensive plantings were established after the military use phase, and due to the low intensity of human interference, nature has thrived over time. A diversity of flora and fauna, including abundant rare species, have colonized the area. Animals such as cattle, sheep and deer have been introduced since the establishment of plant communities. A series of protection plans have been published along with measures to enhance recreational opportunities. To date, $63 \%$ of the park area has been designated as an EU Natura 2000 area, meaning that habitats and threatened species are secured and monitored.

The land use and reclamation history as well as the current preservation prioritization efforts have resulted in a wide range of habitats and landscapes in the park, from meadows, wetlands, and forests to coastal land. Further, the landscape was diversified by an interplay of microclimate, microtopography, soil humidity, and water salinity variations. Recently (2015), it became one of the 14 "Danske Naturparker" (Danish Nature Parks) in Denmark, in which conservational and recreational values are emphasized equally. It is estimated that the park has approximately 1 million visitors per year, and plans have been made for increasing visitation and large investments in recreational facilities (Naturparkplan 2015 - 2020). Overall, the park is suitable as a case study for exploring the relationship of landscape variables and landscape experience.

\section{Database setup}

Web scraping was performed with Flickr's public application programming interface (API) to extract data, including geotagged photos, descriptive text and user information. The JavaScript object notation (JSON) containing a key-value pair of user IDs and photo IDs for posts can be returned by calling the Flickr API request and specifying the geographic range and time span. The URL of Flickr post follows the structure "'https://www.flickr.com/photos/"userID/photoID'. With the obtained URLs, the hypertext markup language (HTML) of the webpage can be requested in a Python environment where different types of metadata can be compiled with regular expressions. The initial data acquisition resulted in 10373 records within a coarse range of the site, of which 2089 were within the precise site boundary. Data cleaning was conducted to remove photo records with content that was too similar, irrelevant to the study topic or had incorrect location information. A maximum of five photos from each user per day was established to counteract bias from overactive users. The final database contained 980 records over a time span of eight years (1.1.2012 to 12.31.2019).

\section{Photo content analysis}


To investigate the types of experiences in the park, the photos were manually categorized. A rather precise photo classification method was adopted initially. For a given photo with attached descriptive information (text such as tags), the examiners independently decided what theme(s) the photo referred to and then included the theme(s) on a list of experience dimensions. The categories of experience were finalized when no new themes emerged from the photos. The initial set of 9 experience dimensions were natural sight, animal, plant, outdoor recreation, scenery, man-made structure, architecture, and feeling expression. However, categorized datasets with an insufficient amount of data may produce an unreliable result for the subsequent spatial analysis - in the first round of categorization, only 24 photos were categorized as feeling expression, 43 were categorized as natural sight, and 71 were categorized as plants. Therefore, the initial dimensions were merged into five meta-dimensions to be used to establish dependent variables. Detailed descriptions and examples for each dimension are presented in Table 2. It should be noted that in practice, some photos may express more than one type of landscape experience and therefore could be assigned to multiple categories.

Table 2 Categorization of photos into five experience dimensions

\begin{tabular}{|c|c|c|c|c|c|}
\hline Criteria & Nature & Animal & Scenery & Engagement & Culture \\
\hline Description & $\begin{array}{l}\text { Plant close-up } \\
\text { view, biophysical } \\
\text { environment, } \\
\text { natural } \\
\text { phenomena, } \\
\text { indication of } \\
\text { wilderness }\end{array}$ & $\begin{array}{l}\text { Animals } \\
\text { living in the } \\
\text { park, } \\
\text { domesticated } \\
\text { or wild } \\
\text { animals, } \\
\text { insects, } \\
\text { mammals, } \\
\text { amphibians, } \\
\text { etc. }\end{array}$ & $\begin{array}{l}\text { Related to } \\
\text { overlooks } \\
\text { and } \\
\text { configuration } \\
\text { of landscape } \\
\text { elements, } \\
\text { and } \\
\text { indicating } \\
\text { space }\end{array}$ & $\begin{array}{l}\text { Related to } \\
\text { human activities, } \\
\text { human } \\
\text { emotions, etc. }\end{array}$ & $\begin{array}{l}\text { Obvious } \\
\text { presence of } \\
\text { man-made } \\
\text { structures in } \\
\text { the park and } \\
\text { architecture. }\end{array}$ \\
\hline Indicators & $\begin{array}{l}\text { Mist, snow, } \\
\text { plant, light, } \\
\text { flower, iconic } \\
\text { tree, grass, } \\
\text { sunset, } \\
\text { deadwood, bog, } \\
\text { meadow, forest, } \\
\text { sea, lake, } \\
\text { season, } \\
\text { wilderness, } \\
\text { natural } \\
\text { landscape, etc. }\end{array}$ & $\begin{array}{l}\text { Bird, insect, } \\
\text { cattle, fowl, } \\
\text { sheep, fox, } \\
\text { wild animals, } \\
\text { toads, horses } \\
\text { raised in the } \\
\text { park, etc. }\end{array}$ & $\begin{array}{l}\text { Natural } \\
\text { landscape, } \\
\text { architectural } \\
\text { land- scape, } \\
\text { mosaic of } \\
\text { nature and } \\
\text { architecture, } \\
\text { skyline, } \\
\text { vista over } \\
\text { lake, sea, } \\
\text { meadow, } \\
\text { configuration } \\
\text { of tree } \\
\text { stands, etc. }\end{array}$ & $\begin{array}{l}\text { Cycling, sports, } \\
\text { picnicking, } \\
\text { walking a dog, } \\
\text { horseback riding, } \\
\text { boating, selfies, } \\
\text { foraging, } \\
\text { walking, running, } \\
\text { motocross, kite } \\
\text { surfing, bird } \\
\text { watching, } \\
\text { fishing, campfire, } \\
\text { golfing, etc. }\end{array}$ & $\begin{array}{l}\text { Facility, board } \\
\text { walk, shelter, } \\
\text { cultural } \\
\text { heritage, dike, } \\
\text { urban texture, } \\
\text { sculpture, } \\
\text { graffiti, iconic } \\
\text { architecture (8 } \\
\text { Tallet, Bella } \\
\text { Sky), railway, } \\
\text { Øresund } \\
\text { Bridge, etc. }\end{array}$ \\
\hline
\end{tabular}




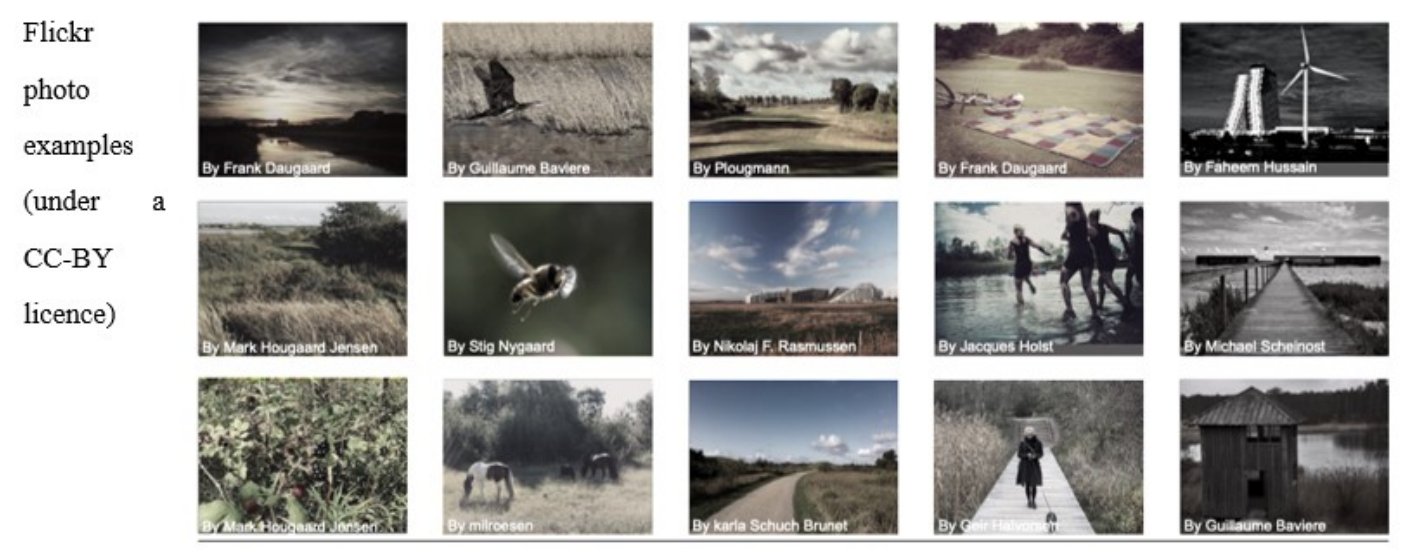

\section{Nature experience dependent variable}

Flickr data with geo-coordinates were imported into ArcGIS Pro for preprocessing. Given the location accuracy of Flickr data, a grid with a $250 \mathrm{~m} * 250 \mathrm{~m}$ cell size covering the whole site area was created to calculate the user count of photos falling into every grid cell (Tenerelli et al. 2016; Heikinheimo et al. 2020). The grid cells within the bird sanctuary were manually removed so that only the accessible areas were considered in the study. The number of users within in a cell (hereafter referred to as the user count) was assigned to the centroid of the corresponding cell as the dependent variable for the multiscale geographically weighted regression (MGWR) modelling.

\section{Potential landscape variables}

The selection of explanatory variables was based on a literature review, the characteristics of the site area, the availability of geodata, and the data type requirements. In landscape studies employing regression modelling methods, Pastur et al. (2016) performed logistic regressions with six explanatory variables: "water", "vegetation", "protected areas", "urban settlements", "accessibility" and "tourism offering". Tenerelli et al. (2016) carried out GWR to study the association between landscape features and peoples' preferences and perceptions of cultural ecosystem services in mountain landscapes. In their study, 14 explanatory variables were used, which included 9 environmental variables (proximity to "sighting points", "water", and "geology interest points"; "average slope", "average altitude", "annual isolation", "protection status", "habitat class", and "number of habitat types") and 5 opportunity setting variables (proximity to "roads", "ski resort", "recreation points", and "human settlement" and "population within $100 \mathrm{~km}$ ").

Inspired by these studies, we used the nearest Euclidean distance between the landscape features and centroid of every cell as the major type of variable because 1) the distance variable provides a straightforward numeric proxy to represent the effects of landscape features; 2) given the flat terrain of the park, topography-related variables such as slope, altitude, and annual isolation, which are more dramatic in mountain areas, were considered less relevant in this study; and 3) the scale of the site area is relatively small; thus, the location of human settlements was not assumed to be a significant variable influencing peoples' destination choices. In this way, a set of potential explanatory variables were established (Table 3): 
Table 3 Potential landscape variables

\begin{tabular}{|c|c|c|c|}
\hline Category & Variable & $\begin{array}{l}\text { Variable } \\
\text { type }\end{array}$ & Data source \\
\hline \multirow[t]{5}{*}{$\begin{array}{l}\text { Landscape } \\
\text { feature }\end{array}$} & $\begin{array}{l}\text { Distance } \\
\text { to water }\end{array}$ & Continuous & Basemap03 (Levin, 2019) \\
\hline & $\begin{array}{l}\text { Distance } \\
\text { to } \\
\text { woodland }\end{array}$ & Continuous & Basemap03 (Levin, 2019) \\
\hline & $\begin{array}{l}\text { Distance } \\
\text { to } \\
\text { meadow }\end{array}$ & Continuous & Basemap03 (Levin, 2019) \\
\hline & $\begin{array}{l}\text { Distance } \\
\text { to trail }\end{array}$ & Continuous & Basemap03 (Levin, 2019) \\
\hline & $\begin{array}{l}\text { Distance } \\
\text { to tourist } \\
\text { attraction }\end{array}$ & Continuous & $\begin{array}{l}\text { Folder of Naturpark Amager } \\
\text { (https://naturparkamager.dk/media/208681/naturparkamag- } \\
\text { er_m65_a3-godkendte-jan-2017.pdf }\end{array}$ \\
\hline \multirow[t]{4}{*}{$\begin{array}{l}\text { Landscape } \\
\text { attribute }\end{array}$} & $\begin{array}{l}\text { Distance } \\
\text { to city } \\
\text { centre }\end{array}$ & Continuous & Basemap03 (Levin, 2019) \\
\hline & $\begin{array}{l}\text { Diversity } \\
\text { of land } \\
\text { use }\end{array}$ & Count & Basemap03 (Levin, 2019) \\
\hline & $\begin{array}{l}\text { Protection } \\
\text { condition }\end{array}$ & Proxy & $\begin{array}{l}\text { Natura 2000-væsentligheds- vurdering af "Naturpark Amager } \\
\text { - Hovedindgange og blå st } \varnothing \text { ttepunkter" }\end{array}$ \\
\hline & $\begin{array}{l}\text { Spatial } \\
\text { openness }\end{array}$ & Proxy & $\begin{array}{l}\text { EEA tree cover density geodata } \\
\text { (https://land.copernicus.eu/pan-european/high-resolution- } \\
\text { layers/forests/tree-cover-density/status-maps/tree-cover- } \\
\text { density-2018) }\end{array}$ \\
\hline
\end{tabular}

\section{Calculation of explanatory variables}

The influence of landscape features was indicated by the distance of landscape features to the central point of the grid cell where the photo was located, which was calculated with the Near tool in ArcGIS. The land use, including water, woodland, meadow and trail, was determined in ArcGIS for every grid cell. The scores for protection conditions were in the range of $1-4$, from poor to good, based on a habitat condition report (2010 -2011) for the area. Spatial openness was indicated by the canopy density in a range of $1-5$ with an increment of $20 \%$, where 1 stands for $0-20 \%$ density, and 5 stands for $80 \%-100 \%$. All explanatory variable values were assigned to the centroid of the corresponding cell.

\section{Spatial analysis and statistics}


To evaluate the variability of the scale effect of landscape variables on the distribution of different categorized experiences, multiscale geographically weighted regression (MGWR) was used (https://sgsup.asu.edu/sparc/multiscale-gwr). Fotheringham et al. (2017) demonstrate the core principle of MGWR; this method ties together the two distinguishing paradoxical features of the scale effect in space: 1) spatial dependence in data - at any location, data can be "borrowed" from the neighbourhood (indicated by the "bandwidth") and weighted according to its distance, in line with Tobler's (1970) first law of geography, and 2) spatial heterogeneity - relationships between dependent variables and explanatory variables are allowed to vary spatially. Thus, MGWR can explicitly identify the scale of the relationship between landscape and experience variables in two ways: 1) identifying the spatial range of influences, indicated by the value of the bandwidth, which reflects the sensitivity to the change in the independent variable in the given relationship; and 2) in combination with a Monte Carlo test, examining heterogeneity in the matrix of parameter estimates (thus reflecting the magnitude of the relationship) of a given independent variable in a series of spatial regression functions.

In addition, we compared the goodness-of-fit of MGWR with that of global regression, a traditional regression method that produces an averaged global value across the space for the whole dataset and disregards any possible spatial scales of the relationships (Tenerelli et al. 2016; Fotheringham et al. 2017; Chang Chien et al. 2020). With the diagnostic statistics for the results of MGWR and global regression, the scale effect of landscape variables would be corroborated if the MGWR model exhibited a better fit than the traditional regression model.

\section{Model calibration and finalization of variables for each experience}

To reduce the chance that significant variables would be underrated due to interference from nonsignificant ones and to obtain the most parsimonious model, the explanatory variables for each experience were finalized. This was done by stepwise forward selection for the calibration of the MGWR model to achieve the best model fit, as measured by the AICc. The final set of variables with the lowest AICc was considered the most relevant possible combination of independent variables from the set of potential variables. The adjusted R-square value of the final model represents the proportion of variance in the dependent variable that can be explained by the model with the selected independent variables.

\section{Interpretation of the MGWR result}

For each centroid of a cell that was associated with values of variables, MGWR was used to calculate parameter estimates of the landscape variables as a function of the experience-related dependent variables (user count). The value of the parameter estimates indicated the magnitude of the influence of the parameter. The variability of the parameter estimates for the regression models was examined by Monte Carlo test, in which a p-value higher than 0.05 indicated that the variability of the parameter estimates over the whole area was not statistically significant. Therefore, that variable was identified as a global variable for the given type of experience. If significant, the parameter estimates indicated a significant varying pattern across the space; accordingly, the independent variable could be interpreted as a local variable. Bandwidth, the number of data points "borrowed" from the neighbourhood of a data point being modelled, can also be seen as an index that reflects the spatial scale - the higher the bandwidth value is, the broader 
the scale of relationships it indicates. In addition, as global regression does not consider the scale effect and assumes that spatial processes are constant over space (Fotheringham et al. 2017), the diagnostic statistics (AICc and adj. R-square) of the MGWR and global regression were compared to see whether the overall fit of the model improved after incorporating the multi-scale factor. This difference can be another sign of the scale effect of landscape variables. The three approaches mentioned above can demonstrate the presence and examine the magnitude of the potential varying scale effects of landscape variables on people's landscape experiences.

A number of parameters regarding the strength, spatial range, and spatial variability of the model and the magnitude of the modelled relationship were obtained by performing the MGWR analysis (elaborated in Table 4). In addition, a CSV file was generated with the coordinates of every cell centroid and parameter estimates of the explanatory variables and their p-values at every centroid. This result file was then imported into GIS software for the visualization of the estimate parameters that reached statistical significance $(p<$ 0.05 ) to illustrate the variability of scale effects on the relationship of the landscape variables to the experience distributions in the park.

Table 4 Description and function of key parameters returned by MGWR

\begin{tabular}{|c|c|}
\hline Parameter & Description and function \\
\hline Bandwidth & $\begin{array}{l}\text { an index reflecting the scale of an explanatory variable's influence on an experience } \\
\text { dimension. The highest value is } 658 \text { in this case, which is the total number of grid cells }\end{array}$ \\
\hline $\begin{array}{l}\text { Global } \\
\text { variable }\end{array}$ & $\begin{array}{l}\text { independent variables with relatively constant parameters that apply to the whole spatial } \\
\text { range in a given relationship }\end{array}$ \\
\hline $\begin{array}{l}\text { Local } \\
\text { variable }\end{array}$ & $\begin{array}{l}\text { independent variables with significantly varying parameters that apply to local scopes in a } \\
\text { given relationship }\end{array}$ \\
\hline $\begin{array}{l}\text { P-value in } \\
\text { Monte } \\
\text { Carlo test }\end{array}$ & used to confirm whether a variable is global or local in this case \\
\hline $\begin{array}{l}\text { Parameter } \\
\text { estimate }\end{array}$ & $\begin{array}{l}\text { indicates the magnitude of the relationship between the explanatory variable and the } \\
\text { dependent variable }\end{array}$ \\
\hline Intercept & $\begin{array}{l}\text { indicates the effects of the other covariables that together influence the dependent } \\
\text { variable except for the variables in the model, e.g., the characteristics of landscape } \\
\text { features, management level, accessibility, context factors, etc. }\end{array}$ \\
\hline $\mathrm{AICc}$ & $\begin{array}{l}\text { the criterion against which the combination of explanatory variables that best explains the } \\
\text { experience value is identified via model calibration }\end{array}$ \\
\hline Adj. R2 & indicates the goodness-of-fit of the final regression model \\
\hline
\end{tabular}

\section{Results}

Experience identified within the study area 
The categorization results for the Flickr photos in the five landscape experience dimensions are reported in Table 5. More than half of the photos were related to animals (64.1\%); the rest of the categories were quantitatively similar, except culture (32.1\%), which was the smallest. However, in regard to the number of users, the statistics reflected a different pattern; culture became the most prominent experience across unique users $(53.6 \%)$, followed by scenery $(50.3 \%)$ and nature $(49.7 \%)$, whereas the fewest users recorded animal experiences (24.9\%). In comparing the counts of photo records vs. users, experiences related to nature $(45.2 \%$ vs. $49.7 \%)$ and engagement $(36.0 \%$ vs. $39.7 \%)$ were relatively consistent. However, a significant disparity between counts of photos and users was observed in animal (64.1\% vs. $24.9 \%)$ and culture (32.1\% vs. 53.6\%) experiences.

Table 5 Number and proportion of Flickr photos and users corresponding to the five experiences (the total user and photo percentages can exceed $100 \%$, as one photo may fall into multiple categories)

\begin{tabular}{|lllllll|}
\hline Count & Nature & Animal & Scenery & Engagement & Culture & Total \\
\hline Photos & $366(45.2 \%)$ & $519(64.1 \%)$ & $345(42.6 \%)$ & $292(36.0 \%)$ & $260(32.1 \%)$ & 980 \\
\hline Users & $90(49.7 \%)$ & $45(24.9 \%)$ & $91(50.3 \%)$ & $72(39.7 \%)$ & $97(53.6 \%)$ & 181 \\
\hline
\end{tabular}

The nonconformity of the numbers of photos and users leads us to two findings. The first is related to social media posting behaviour; that is, people may tend to post several photos about animals at one time, whereas people may share only a few photos for a cultural experience. The second hypothesis, however, highlights the characteristics of different experiences; that is, the animal experience is more diverse, dynamic, and scattered than the cultural experience, which is often connected to static and fixed structures.

Therefore, it is noted that the nonconformity of the numbers of photos and users should be taken into consideration when analysing social media data. This article used user count as the dependent variable for the purpose of counteracting the possibility that a single user may take multiple photos of the same object in the same spatial setting; in other analyses, the photo count may be more relevant.

\section{Landscape variable scale effects on experience categories and parameter estimates}

The parameter estimates for variables that reached statistical significance in relation to the five experience categories (95\% confidence interval) are visualized in Fig. 2. To facilitate an understanding of the results of the summary of parameter estimate surfaces, the following order of interpretation was applied:

1. Which pairs of landscape variables and experiences are found to be associated?

2. What is the range (coloured area) of the relationship of the pairs of identified variables?

3. How are the values of the parameter estimates (colour spectrum) distributed in the influenced area? 
First, all ten explanatory variables exhibited some impact. Water and tourist attractions were found to be landscape features that influenced all five experiences, while the rest influenced some of the experiences. In general, animal experience was the dimension influenced by the largest number of landscape variables (water, woodlands, trails, tourist attractions, city centre, protection condition and land use diversity), followed by engagement experience, which was influenced by six landscape variables (water, meadows, woodlands, trails, tourist attractions, and land use diversity). Both nature and culture experiences were found to be associated with four landscape variables (water, trail, tourist attraction and land use diversity; and water, tourist attraction, city centre and land use diversity, respectively). The scenery experience was related to the smallest number of variables (water, tourist attraction and spatial openness).

Second, it can be observed from the different ranges of coloured areas and values of bandwidth in the visualization maps that the effects of the variables on experiences operate at different scales and that some of the relationships were significant across the whole park. These relationships include the relationship between water and nature, scenery, engagement and culture experiences; trails and nature experiences; tourist attractions and animal experiences; and land use diversity and animal experiences. For the rest of the relationships, landscape variables were significant only at a local scale. Such variables were meadows, woodlands, distance to city centre, protection condition and spatial openness.

Third, the intensity of the colour reveals the strength of the spatial relationships between variables and experience dimensions. Furthermore, the heterogeneity of the parameter estimates can be explicitly indicated by the $p$-value from the Monte Carlo test, with which global variables can be distinguished from local variables (marked with asterisks in Fig. 2). It is clear from the results that the effect of the same landscape feature on a given experience changed across space and that the patterns of these effects were different for different types of experience.

\section{Statistical assessment of the resulting MGWR and the improvement in the model achieved by considering the scale effect}

The goodness-of-fit of the models suggested by the diagnostic statistics (adj. R-square and AICc) was measured along with the MGWR results. In this way, the global regression and MGWR were compared to verify the improvement achieved with MGWR and thereby corroborate the presence of scale effects (Table 6). The AICc values of the MGWR models for all five experiences were lower than those of the global regression models, with a difference ranging from 61.578 (Engagement) to 103.777 (Animal); these results indicate the stronger explanatory power of MGWR. Additionally, the model fit was improved according to the adj. R-square values, with $27.8 \%$ of the variance in the dependent variable explained for animal experiences, $26.2 \%$ explained for nature, $25.1 \%$ explained for culture, $22.1 \%$ explained for engagement and $18.4 \%$ explained for scenery. This suggests that the landscape variables account better for animal, nature and culture experiences than for engagement and scenery experiences; this may be partly because the variables related to engagement and scenery may be too intricate to be modelled with the variables selected in the present study. Generally, the MGWR models exhibited an improved fit compared with the global regression models, and the influence of scale on the effect of landscape variables on the five experiences was confirmed and intuitively presented by this multi-scale analytical approach. 
Table 6 Statistical diagnosis of MGWR, global regression and modelling improvement

\begin{tabular}{|lllllll|}
\hline $\begin{array}{l}\text { Regression } \\
\text { method }\end{array}$ & $\begin{array}{l}\text { Diagnostic } \\
\text { criterion }\end{array}$ & \multicolumn{2}{l}{ Experience dimension } & & \\
\cline { 3 - 7 } & NGWR & Nature & Animal & Scenery & Engagement & Culture \\
& Adjusted R & 0.262 & 0.278 & 0.184 & 0.221 & 0.251 \\
\cline { 2 - 7 } & AlCc & 1711.149 & 1711.418 & 1770.734 & 1739.497 & 1731.121 \\
\hline $\begin{array}{l}\text { Global } \\
\text { regression }\end{array}$ & Adjusted R & 0.122 & 0.095 & 0.046 & 0.113 & 0.077 \\
\cline { 2 - 7 } & AlCc & 1792.867 & 1815.195 & 1846.100 & 1801.075 & 1825.171 \\
\hline Difference & Adjusted R & 0.140 & 0.183 & 0.138 & 0.108 & 0.174 \\
& AlCc & -81.718 & -103.777 & -75.366 & -61.578 & -94.05 \\
\hline
\end{tabular}

\section{Discussion}

\section{Identified experiences and the existence of scale effects on the associated landscape variables}

The public's experiences in the park were inductively identified and categorized into five experience dimensions: animal, nature, scenery, engagement and culture. These categories are often used in photo content analysis across social media studies, with slight differences in the dimension names (Zhang et al. 2020; Richards and Tunçer 2017; Callau et al. 2019; Tenerelli et al. 2016; Richards and Friess 2015; Retka et al. 2019; Hale et al. 2019). For example, the animal dimension has been labelled as "wildlife" or "biodiversity"; nature has been labelled as " plants" or "natural landscape"; engagement has been labelled as "physical use of landscape", "people", "social recreation", "artistic or cultural expressions and appreciation", or "emotional reactions"; scenery has been labelled as "landscape" or "aesthetic"; and culture has been labelled as "cultural heritage", "infrastructure appreciation" "history", or "sense of place".

Each type of experience was found to be significantly correlated with a certain group of landscape variables rather than with all landscape variables; moreover, instead of a consistent pattern, varying patterns at multiple scales were explicitly discerned in the relationship of landscape variables to different types of experiences.

First, the general positive relationship between water bodies and landscape experiences has long been articulated in studies relating to landscape aesthetics and preferences (e.g., Ode et al. 2008). Further, this positive relationship has also been articulated in studies based on social media activity (Hamstead et al. 2018; Wang et al. 2018; Tieskens et al. 2018; Heikinheimo et al. 2020). However, in contrast to these studies, we found that such an influence was not always positive but depended on the local geographical settings. An inspection of the photo content and the spatial settings of these specific positive and negative geographic zones helps to explain why these patterns developed. The positive effect of water on certain experiences (nature, scenery, engagement and culture) may be ascribed to the common perception that water features can be natural and recreational elements and are often a backdrop for scenery and culture 
experiences. However, in regard to animal experience, the results indicated that water bodies had mixed effects: in natural surroundings, water bodies acted as important animal habitats (mostly for wading birds, in this case), resulting in a high animal experience value; however, in more highly managed environments, such as the golf course, the scale effect of water on animal experiences became negative. This point highlights the importance of the specific social-ecological context of landscape features, which is also described in other studies of social media photos in mountainous landscapes (Foltête et al. 2020; Tenerelli et al. 2016).

Second, as also documented by Foltête et al. (2020), green spaces, including woodlands and meadows, have a somewhat mixed relationship (depending on their visual weight in a spatial setting) to landscape preferences; in our study, we were able to link this mixed relationship to the animal and engagement experiences specifically. An analysis of the Flickr photo data was performed to explain this pattern. Regarding the negative effect of woodland features on animal experience, the animals photographed were primarily open land species such as wading birds, meadow insects and cows. One explanation for this may be that the interference of the branches and leaves of thicket and tree canopies may add to the difficulties of photographing animals (for instance, birds) in woodlands. The negative effect of woodlands on the engagement experience in the areas around the seashore indicates that people appear to avoid enclosed areas, such as coastal woodlands in this case, and prefer more open areas, such as coastal meadows. Indeed, the activities recorded in these areas are mostly connected with the sea and coast (such as coastal cycling, fishing, swimming, kayaking, kite surfing, sun bathing); therefore, trees, in these contexts, could possibly have a negative effect. However, trees were found to be a positive feature at the northern entrance, near the city centre. The content of the records (the photos and the associated text) revealed that in this area, visitors from the inner city tended to engage in everyday physical exercises such as walking, running, and horseback riding as well as emotional expression related to the change of seasons, silence, natural phenomena, etc. Therefore, the role of woodlands differs in terms of the type of landscape experience, the exact spatial context of the experience, and the ways of interacting with nature.

Third, the positive influence of accessibility (in terms of roads and trails) on social media activity (Hamstead et al. 2018; Wang et al. 2018) was confirmed for only three of the experiences: nature, animal and engagement. This result suggests that these types of experience might often occur simultaneously (during the visitors' activities) and thus tend to be clustered close to the trails.

Fourth, social media data are often positively related to the proximity to the city centre (Tenerelli et al. 2016; Heikinheimo et al. 2020; Guerrero et al. 2016). However, this relationship was found to be positive only for animal and culture experiences in this study, indicating that proximity to the city centre can influence visitor destination choices when they come to the park for these experiences.

Fifth, the purely negative relationship reported for protective conditions and animal experience in our data might seem counterintuitive and call for further exploration. Indeed, others have reported a more mixed effect of cultural ecosystem services and the protect condition variable on crowdsourced indicators (Tenerelli et al. 2016). However, this divergence may be primarily influenced by the two restricted-access bird sanctuaries in our study area (the empty areas on the parameter estimate surface). Our results therefore 
reflect the design of the specific protected areas in terms of permitted access as well as the concentration of recreational trail facilities in the study area.

Sixth, land use diversity presented mixed patterns of influence on experiences, as suggested in Tenerelli et al.'s (2016) study. Land use diversity was found to be positively correlated with nature, animal and engagement experiences but negatively correlated culture experiences in some locations. This again might relate to the design of the park, where cultural elements are concentrated in more homogenous parts of the park.

Finally, the positive influence of the openness variable found in other studies (Foltête et al. 2020; Johnson et al. 2019; Hausmann et al. 2017) was significant only for scenery experiences in our study.

\section{Novel application of MGWR approach}

The difference between the findings of the present study and those of previous studies mentioned above can be attributed to the special consideration given to the scale effect. We employed an approach that allowed us to calibrate spatial models with separate bandwidths for each sample point for the best-fit regression results, and a more precise range of landscape variable influence could be suggested by the bandwidth value. In addition, the parameter estimates were calculated for each sample point, resulting in a surface that explicitly shows the magnitude of the influence. Therefore, instead of an averaged measure of the influences, this article identified the spatial ranges and magnitudes of the positive or negative influences.

MGWR has been increasingly used in recent studies to better account for spatial heterogeneity and explicitly evaluate scale-related parameters in modelling spatial relationships. Chang Chien et al. (2020) assessed the robustness of OLS, GWR and MGWR in studying the relationship of experts' physical criteria of wilderness and public perception across the UK and concluded that MGWR, by calibrating multiple bandwidths for the variables, was capable of offsetting the collinearity of explanatory variables, resulting in stable and consistent parameter estimates. Gosal et al. (2021) applied the MGWR approach to identifying stationary and nonstationary spatial variables in a natural area visitation study in Europe and North America.

However, these large-scale case studies did not pay much attention to linking statistical results with the actual interactions of people and the environment (i.e., experiences and spatial characteristics). In contrast, the present study was dedicated to precisely interpreting the detailed patterns revealed by the MGWR modelling exercise, which allowed us to analyse and explore the details of the multiple statistical relationships between landscape variables and landscape experiences. We believe this study has demonstrated the capabilities and possibilities of using MGWR to better understand the contextualized realities of landscape experiences within a specific case study area at the park level.

\section{Limitations of the study}

Although relationships between landscape variables and the distribution of social media data can be obtained from the results of analyses such as those in this study, locating the exact causes of these relationships is still challenging. It is unclear whether it is truly the geographic effect of a landscape variable 
or the effect of the non-landscape covariable, such as those that have been used to explain the results in this paper, e.g., the photography process, intensity of maintenance, or activities that are not directly stimulated by the landscape but are predetermined by visitors, that determines the relationship. This adds to the challenge of determining which landscape variables are relevant to the study. Moreover, questions about whether the pattern is real need to be assessed; there may be instances of "apophenia" where one tends to seek plausible connections to find patterns that may not actually exist (Boyd and Crawford, 2013).

Additionally, an analytical compromise took place during the spatial modelling and has to be acknowledged: the dependent variable for the categorized experiences was estimated as the value of the aggregated number of users within a given range, and the potential impacts of landscape features were simplified into distance measures when the landscape features had differentiating characteristics, such as the size and shape of a water body, area of a woodland or meadow, or density of trails, or spatial characteristics, such as the configuration of landscape features, depths of view, etc. Moreover, in reality, landscape features and attributes can mediate in situ experiences in a much more intricate way than that considered in this study.

\section{Implications for future research}

Despite the limitations above, the MGWR approach elicited a spatially explicit quantification of the effect of landscape variables with regard to categorized landscape experiences as an expansion of traditional assessments of simply positive or negative landscape effects and indicator-based approaches (Ode et al 2008a, 2009b; Paracchini et al. 2014). Therefore, the demonstrated approach of using MGWR on the experience dimensions of social media activity might facilitate a process of seeking the reasons behind these experiences by linking collective trends with individual features. This may open up opportunities to broaden the current understanding of the associations of biophysical landscapes with the various types of experiences people can obtain from authentic in situ interactions within landscapes. Using this approach, it is also possible to find evidence for the kinds of hypothetical associations that are often applied in design and planning processes or to uncover new potential associations that had not been thought of before.

Geolocated photos associated with informative text from social media enable a thorough categorization of in situ experiences. However, since treating experiences as points in space can result in the loss of the "density" of experiences, in future research, more sophisticated metrics need to be incorporated as landscape variables, such as the skyline, depth line, indexes of land use diversity, etc. (Foltête et al. 2020). In addition, there are numerous variables other than purely geographic variables that are involved in the process of experiencing nature and landscape, e.g., individual visitor motives, expectations, values, preferences, visitation history, and perceptions of site value and atmosphere (Brown et al. 2020; Chiesura, 2004; Zhang et al., 2013; Bertram and Rehdanz 2015; Atauri et al. 2000). Thus, researchers may adopt combined methods that involve more qualitative approaches in the future (Hegetschweiler et al. 2017). Furthermore, we highlight the need for possible cross-case studies to be conducted in other contexts at different scales to test the validity of the patterns of relationships of landscape and experiences found in Amager Nature Park. With the popularization of social media and the development of technological and 
analytical methods, the potential of the novel methods demonstrated in this article can be expected to be realized in a wider range of studies exploring the value of natural landscapes for human wellbeing.

\section{Conclusion}

This paper aimed to advance the study of the mediating effects of landscape on landscape experiences by tapping into the scale effects of landscape variables in relation to specific dimensions of experiences in an urban nature park. The results suggest that even a single landscape variable can exert an influence on different landscape experiences at multiple scales and that its effects can be both positive and negative according to the different geographical contexts. Among the other relationships identified, water and woodlands, which are frequently considered to positively influence the landscape experience in the literature, were found to have mixed effects on different experiences, and the scale range and magnitude of these impacts were highly context-dependent. The identification of such nuances in these relationships can be attributed to the particular consideration given to the scale effect. We employed an approach that allowed us to calibrate the spatial models with separate bandwidths for each sample point to achieve the best-fit regression results; thus, a more precise range of influence of the landscape variables could be determined by the bandwidth value. In addition, the parameter estimates were calculated for each sample point, resulting in a surface that explicitly showed the magnitude of the influence. Therefore, instead of an averaged measure of the influences, this article identified the spatial ranges and magnitudes of positive or negative influence.

Limitations such as data availability, reliability of the modelling method and the proper incorporation of explanatory variables were significant barriers to obtaining a more in-depth understanding of the experiential dimension of people's interactions with the landscape, and the interrelationships among different types of experiences that take place in the same spatial setting need to be further studied.

In the practice of landscape planning, design and management, an awareness of the fact that landscape variables are unlikely to have the same effects at different scales, either for landscape experiences or across an entire area, puts a more critical focus on the specific arrangements and selective augmentation of landscape features and attributes linked to proposed nature experiences. Finally, the present study suggests a scientific means of effectively enhancing multiple experiences by prioritizing certain landscape features and attributes in the targeted locations; such an approach can be used to optimize the overall outcomes with regard to urban nature experiences and minimize costs and trade-offs.

\section{Declarations}

Acknowledgements We are grateful to the anonymous reviewers for their valuable comments on the manuscript of this paper.

Funding: No funding was received to assist with the preparation of this manuscript.

Conflicts of interest/Competing interests: Both authors have no financial or proprietary interests in any material discussed in this article. 


\section{Compliance with ethical standards}

Consent to participate: Not applicable

Consent for publication: Both authors have consented to publication of this material.

Availability of data and material: The datasets generated during and/or analyzed during the current study are available from the corresponding author on reasonable request.

Code availability: The Python scripts used to produce dataset in the study is available from the corresponding author on reasonable request.

Authors' contributions: Both of the authors contributed to the conceptualization and methodology of the study. Formal analysis, investigation, visualization, and software were performed by PC. The first draft of the manuscript was written by PC and reviewed by ASO, who provided resources and supervision.

\section{References}

Arnberger A, Aikoh T, Eder R, Shoji Y, Mieno T (2010) How many people should be in the urban forest? A comparison of trail preferences of Vienna and Sapporo forest visitor segments. Urban Forestry \& Urban Greening 9(3):215-225

Assessment ME (2005) Ecosystems and human well-being. Island press United States of America

Atauri JA, Bravo MA, Ruiz A (2000) Visitors' landscape preferences as a tool for management of recreational use in natural areas: A case study in Sierra de Guadarrama (Madrid, Spain). Landscape Research 25(1):4962

Bakolis I, Hammoud R, Smythe M et al (2018) Urban Mind: Using Smartphone Technologies to Investigate the Impact of Nature on Mental-Well-Being in Real Time. Bioscience 68(2):134-145

Bertram C, Rehdanz K (2015) Preferences for cultural urban ecosystem services: Comparing attitudes, perception, and use. Ecosystem Services 12:187-199

Boyd D, Crawford K Six provocations for big data. In: A decade in internet time: Symposium on the dynamics of the internet and society, 2011.

Brown G, Montag JM, Lyon K (2012) Public Participation GIS: A Method for Identifying Ecosystem Services. Society \& Natural Resources 25(7):633-651

Brown G, Reed P, Raymond CM (2020) Mapping place values: 10 lessons from two decades of public participation GIS empirical research. Applied Geography 116:102156

Calcagni F, Maia ATA, Connolly JJT, Langemeyer J (2019) Digital co-construction of relational values: Understanding the role of social media for sustainability. Sustainability Science 14(5):1309-1321 
Callau AÀ, Albert MYP, Rota JJ, Giné DS (2019) Landscape characterization using photographs from crowdsourced platforms: content analysis of social media photographs. Open Geosciences 11(1):558-571

Chan KMA, Satterfield T, Goldstein J (2012) Rethinking ecosystem services to better address and navigate cultural values. Ecological Economics 74:8-18

Chien Y-MC, Carver S, Comber A (2020) Using geographically weighted models to explore how crowdsourced landscape perceptions relate to landscape physical characteristics. Landscape and Urban Planning 203:103904

Chiesura A (2004) The role of urban parks for the sustainable city. Landscape and urban planning 68(1):129-138

De Groot RS, Alkemade R, Braat L, Hein L, Willemen L (2010) Challenges in integrating the concept of ecosystem services and values in landscape planning, management and decision making. Ecological complexity $7(3): 260-272$

Foltête J-C, Ingensand J, Blanc N (2020) Coupling crowd-sourced imagery and visibility modelling to identify landscape preferences at the panorama level. Landscape and Urban Planning 197:103756

Fotheringham AS, Yang W, Kang W (2017) Multiscale geographically weighted regression (MGWR). Annals of the American Association of Geographers 107(6):1247-1265

Garcia-Martin M, Fagerholm N, Bieling C et al (2017) Participatory mapping of landscape values in a PanEuropean perspective. Landscape Ecology 32(11):2133-2150

Garrod B (2007) A snapshot into the past: The utility of volunteer-employed photography in planning and managing heritage tourism. Journal of Heritage Tourism 2(1):14-35

Gosal AS, Giannichi ML, Beckmann M et al (2021) Do drivers of nature visitation vary spatially? The importance of context for understanding visitation of nature areas in Europe and North America. Science of The Total Environment:145190

Guerrero P, Møller MS, Olafsson AS, Snizek B (2016) Revealing cultural ecosystem services through Instagram images: The potential of social media volunteered geographic information for urban green infrastructure planning and governance. Urban Planning 1(2):1-17

Hale RL, Cook EM, Beltrán BJ (2019) Cultural ecosystem services provided by rivers across diverse socialecological landscapes: A social media analysis. Ecological Indicators 107:105580

Hamstead ZA, Fisher D, llieva RT, Wood SA, McPhearson T, Kremer P (2018) Geolocated social media as a rapid indicator of park visitation and equitable park access. Computers, Environment and Urban Systems 72:38-50 
Hausmann A, Toivonen T, Heikinheimo V, Tenkanen H, Slotow R, Di Minin E (2017) Social media reveal that charismatic species are not the main attractor of ecotourists to sub-Saharan protected areas. Scientific reports $7(1): 1-9$

Hegetschweiler KT, de Vries S, Arnberger A et al (2017) Linking demand and supply factors in identifying cultural ecosystem services of urban green infrastructures: A review of European studies. Urban forestry \& urban greening 21:48-59

Heikinheimo V, Minin ED, Tenkanen H, Hausmann A, Erkkonen J, Toivonen T (2017) User-generated geographic information for visitor monitoring in a national park: A comparison of social media data and visitor survey. ISPRS International Journal of Geo-Information 6(3):85

Heikinheimo V, Tenkanen H, Bergroth C, Järv O, Hiippala T, Toivonen T (2020) Understanding the use of urban green spaces from user-generated geographic information. Landscape and Urban Planning 201:103845

Huais PY (2018) multifit: an R function for multi-scale analysis in landscape ecology. Landscape Ecology 33(7):1023-1028

Ilieva RT, McPhearson T (2018) Social-media data for urban sustainability. Nature Sustainability 1(10):553565

Ittelson WH Environment and cognition. In, 1973. Seminar Press

Johnson ML, Campbell LK, Svendsen ES, McMillen HL (2019) Mapping urban park cultural ecosystem services: a comparison of twitter and semi-structured interview methods. Sustainability 11(21):6137

Kaae BC, Holm J, Caspersen OH, Gulsrud NM (2019) Nature Park Amager-examining the transition from urban wasteland to a rewilded ecotourism destination. Journal of Ecotourism 18(4):348-367

Levin G, Jepsen MR, Blemmer MB (2012) Technical documentation of a model for elaboration of a land-use and land-cover map for Denmark. Aarhus University, DCE-Danish Centre for Environment and Energy: Aarhus, Denmark:47

McCay-Peet L, Quan-Haase A (2017) What is social media and what questions can social media research help us answer. The SAGE handbook of social media research methods:13-26

Naturstyrelsen, Københavns Kommune, Tårnby Kommune, Dragør Kommune og By \& Havn (2019) naturparkplan 2020-2025 - Naturpark Amager. https://naturparkamager.dk/media/274699/naturparkplan20-25_endelig_version2_ lav-oploesning.pdf

O’Brien L, De Vreese R, Kern M, Sievänen T, Stojanova B, Atmiş E (2017) Cultural ecosystem benefits of urban and peri-urban green infrastructure across different European countries. Urban Forestry \& Urban Greening 24:236-248 
Ode Å, Fry G, Tveit MS, Messager P, Miller D (2009) Indicators of perceived naturalness as drivers of landscape preference. Journal of environmental management 90(1):375-383

Ode $\AA$, Tveit MS, Fry G (2008) Capturing landscape visual character using indicators: touching base with landscape aesthetic theory. Landscape research 33(1):89-117

Paracchini ML, Zulian G, Kopperoinen L et al (2014) Mapping cultural ecosystem services: A framework to assess the potential for outdoor recreation across the EU. Ecological indicators 45:371-385

Pastur GM, Peri PL, Lencinas MV, García-Llorente M, Martín-López B (2016) Spatial patterns of cultural ecosystem services provision in Southern Patagonia. Landscape ecology 31(2):383-399

Pickering C, Walden-Schreiner C, Barros A, Rossi SD (2020) Using social media images and text to examine how tourists view and value the highest mountain in Australia. Journal of Outdoor Recreation and Tourism 29:100252

Retka J, Jepson P, Ladle RJ et al (2019) Assessing cultural ecosystem services of a large marine protected area through social media photographs. Ocean \& Coastal Management 176:40-48

Richards DR, Friess DA (2015) A rapid indicator of cultural ecosystem service usage at a fine spatial scale: Content analysis of social media photographs. Ecological Indicators 53:187-195

Richards DR, Tunçer B (2018) Using image recognition to automate assessment of cultural ecosystem services from social media photographs. Ecosystem services 31:318-325

Russell R, Guerry AD, Balvanera P et al (2013) Humans and Nature: How Knowing and Experiencing Nature Affect Well-Being. Annual Review of Environment and Resources 38(1):473-502

Ruths D, Pfeffer J (2014) Social media for large studies of behavior. Science 346(6213):1063-1064

SNC-Lavalin Atkins (2020) Natura 2000-væsentlighedsvurdering af 'Naturpark Amager - Hovedindgange og blå støttepunkter' - Vurdering af rekreative faci- liteter beliggende i henholdsvis Københavns Kommune og Tårnby Kommune. https://tbst.dk/da/-/media/TBST-DA/Miljoevurdering/Lister/VVMdokumenter/Havne/2020/Naturpark-Amager/N2000VV-Naturpark-Amager.pdf

Taylor L, Hahs AK, Hochuli DF (2018) Wellbeing and urban living: nurtured by nature. Urban Ecosystems 21(1):197-208

Tenerelli P, Demšar U, Luque S (2016) Crowdsourcing indicators for cultural ecosystem services: A geographically weighted approach for mountain landscapes. Ecological Indicators 64:237-248

Tieskens KF, Van Zanten BT, Schulp CJ, Verburg PH (2018) Aesthetic appreciation of the cultural landscape through social media: An analysis of revealed preference in the Dutch river landscape. Landscape and Urban Planning 177:128-137 
Tobler WR (1970) A computer movie simulating urban growth in the Detroit region. Economic geography 46(sup1):234-240

Toivonen T, Heikinheimo V, Fink C et al (2019) Social media data for conservation science: A methodological overview. Biological Conservation 233:298-315

Wang Z, Jin Y, Liu Y, Li D, Zhang B (2018) Comparing social media data and survey data in assessing the attractiveness of Beijing Olympic Forest Park. Sustainability 10(2):382

Wilkie S, Clements H (2018) Further exploration of environment preference and environment type congruence on restoration and perceived restoration potential. Landscape and Urban Planning 170:314-319

Zhang H, Chen B, Sun Z, Bao Z (2013) Landscape perception and recreation needs in urban green space in Fuyang, Hangzhou, China. Urban Forestry \& Urban Greening 12(1):44-52

Zhang H, Huang R, Zhang Y, Buhalis D (2020) Cultural ecosystem services evaluation using geolocated social media data: a review. Tourism Geographies:1-23

\section{Figures}

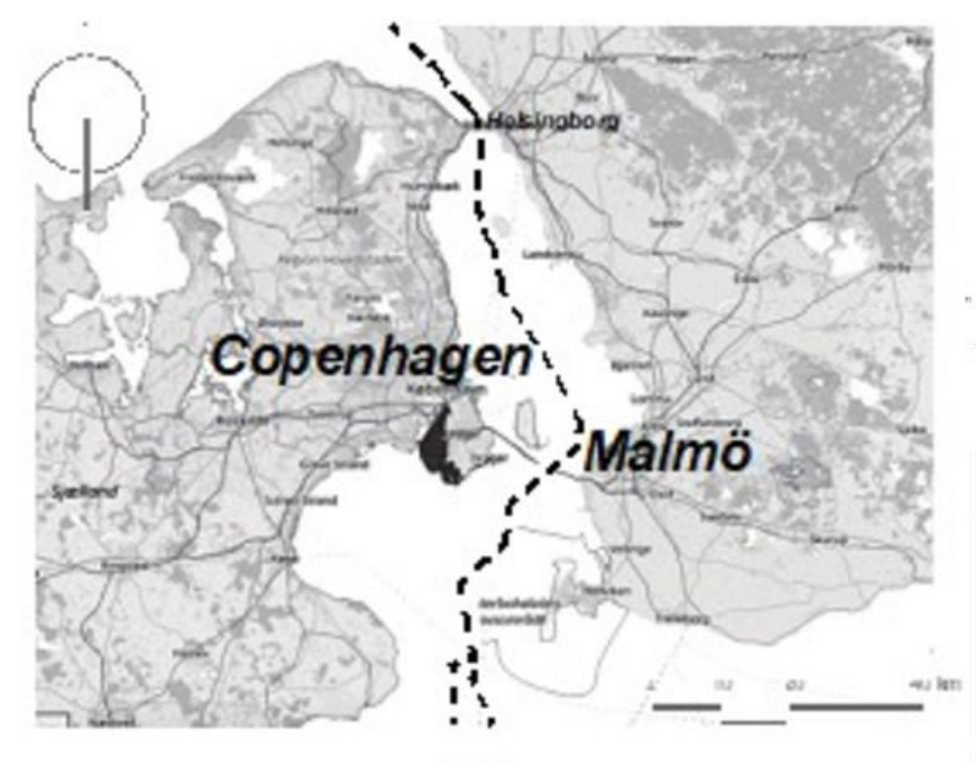

(a)

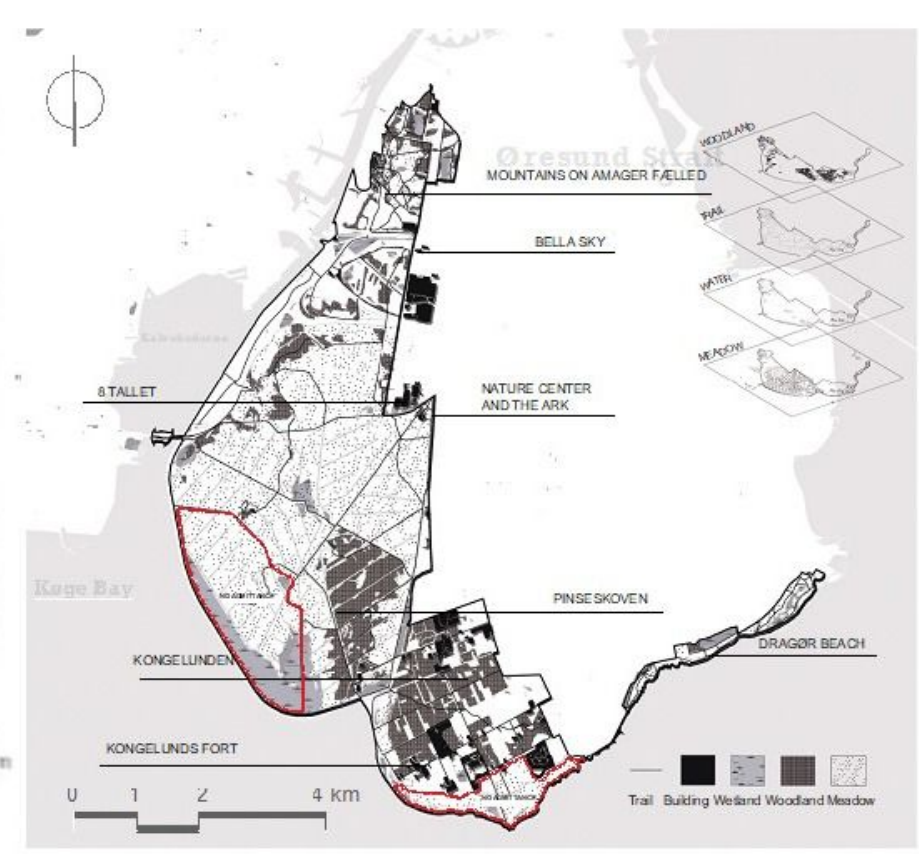

(b)

\section{Figure 1}

a The location of Amager Nature Park is at the fringe of the city of Copenhagen and connected to Malmö with $a$ bridge $b$ land use in the study area (data source: Open Street Map, Styrelsen for Dataforsyning og Effektivisering, Basemap of Denmark, 2018). Note: The designations employed and the presentation of the material on this map do not imply the expression of any opinion whatsoever on the part of Research Square 
concerning the legal status of any country, territory, city or area or of its authorities, or concerning the delimitation of its frontiers or boundaries. This map has been provided by the authors.
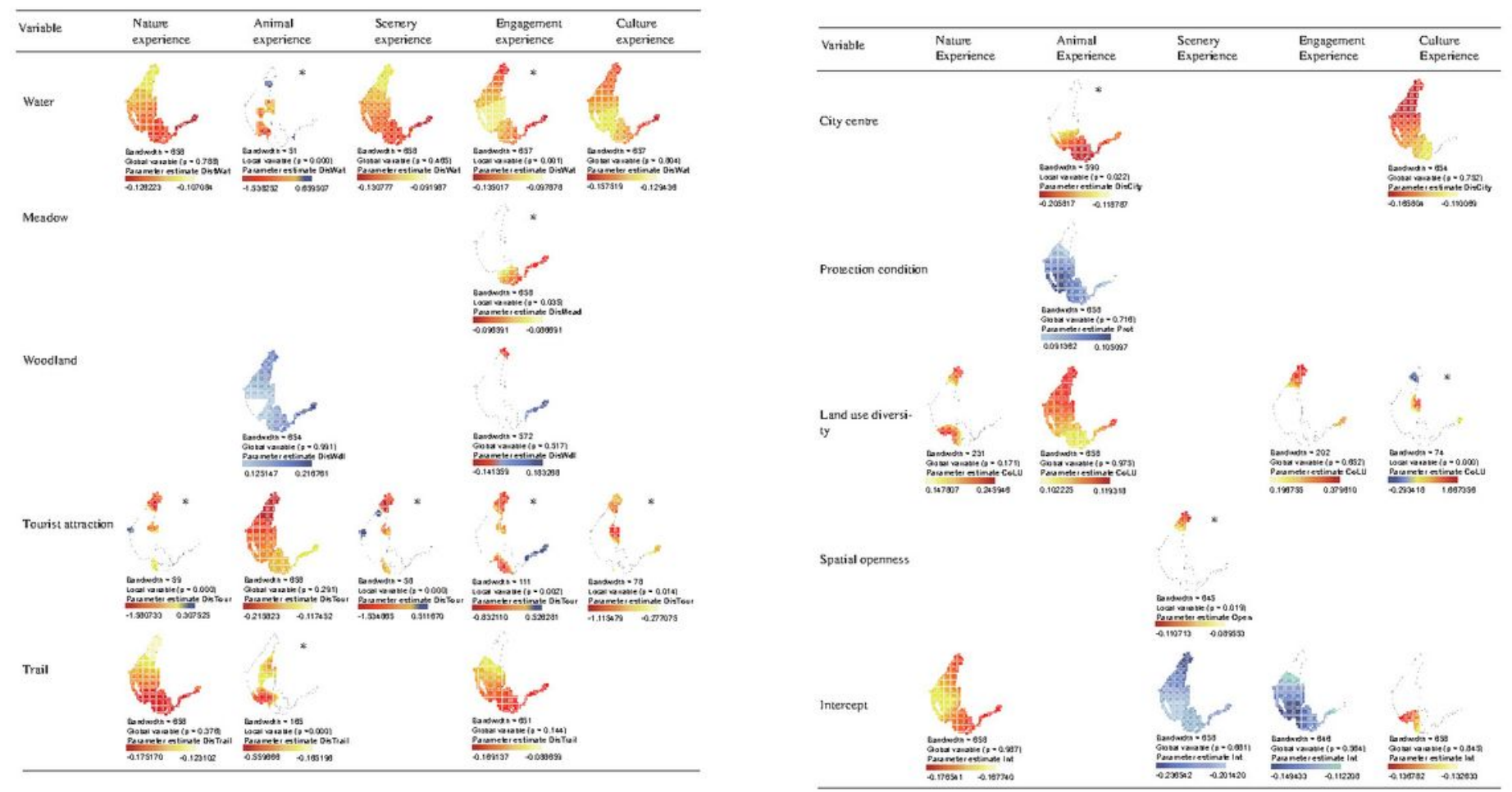

\section{Figure 2}

Visualization of the parameter estimates of landscape variables in relation to five experiences (within a 95\% confidence interval). The parameter estimate surfaces where landscape variables act as local variables in the given relationship are marked with asterisks $\left({ }^{*}\right)$; the rest are global variables. Areas in warm colours suggest that the landscape variable has a positive influence; cold colours indicate a negative influence. The colour intensity corresponding to the values of the parameter estimates for a variable reflect the strength of the relationship between the landscape experience and the explanatory variable 